http://www.tandf.co.uk/journals

\title{
Rationales for Government Intervention in the Commercialization of New Technologies
}

\author{
JUKKA-PEKKA SALMENKAITA \& AHTI SALO
}

\begin{abstract}
The paper examines rationales relevant to the evolving roles of government intervention and private venture capital industry in the commercialization of new technologies. Specifically, government interventions may aim to mitigate market and systemic failures, eliminate structural rigidities, or respond to anticipatory myopia. Ex ante, constructive, and ex post evaluations are discussed in relation to the possibility that agencies responsible for policy implementation may intervene even in situations in which the benefits of their interventions are not necessarily transparent.
\end{abstract}

\section{Introduction}

The role of science and technology (S\&T) policies in fostering economic growth has received increasing attention by economists, policy-makers, and practitioners. ${ }^{1}$ The ways to conceptualize innovation have evolved from unidirectional 'science-push' models towards more complex models that account for interactions between science, technology and markets. ${ }^{2}$ Moreover, institutional structures to support innovation processes have received considerable attention in comparative analyses, as exemplified by the adoption of the concept of a national innovation system in theoretical and empirical research. ${ }^{3}$

In spite of conceptual advances, econometric models and illustrative case studies, there are no straightforward answers to the question of what elements an innovation policy should include, or how such policies should be implemented. ${ }^{4}$ Innovation policies can emphasize basic research and technology development (e.g. public funding of basic research), exploitation of research infrastructure (e.g. university-industry collaboration), support of industrial technology development (e.g. tax subsidies for R\&D), technology adoption, and technical standardization, for instance. Some of these policies are best implemented through legislation, while others call for active participation of civil servants in government agencies, or even extensive collaboration with the private sector.

One of the difficulties in policy design is that while one policy may mitigate an identified market failure, other government or systemic failures may remain or, at worst, be created. ${ }^{5}$ Mowery ${ }^{6}$ defined 'technology policy' as 'policies that are intended to influence the decisions of firms to develop, commercialize or adopt new technologies'. For the

Jukka-Pekka Salmenkaita is at the Nokia Research Center, P.O. Box 407, 00045 Nokia Group, Finland (E-mail: jukkapekka.salmenkaita@nokia.com) and Ahti Salo, Systems Analysis Laboratory, Helsinki University of Technolgy, P.O.Box 1100, 02015 HUT, Finland (E-mail: ahti.salo@hut.fi).

Rémi Barré, Mari Hjelt, David Mowery, Juha Oksanen, Mikko Uusitalo, Pentti Vuorinen and three anonymous referees provided valuable comments on earlier versions of this paper. We appreciate the financial support from the Ministry of Trade and Industry in Finland. 
purposes of this paper, 'innovation policy' refers to policies that are intended to influence the behavior of both public and private organizations in the development and commercialization of new technologies. Thus, aspects of technology adoption are excluded, while policies that seek to influence non-firm organizations (e.g. universities, research institutes) are included. More specifically, 'government intervention' subsumes the mechanisms through which the government deliberately influences resource allocation decisions in order to facilitate technology development and commercialization.

In part, this paper is motivated by recent structural changes in national innovation systems and, specifically, by the shifting roles of private and public actors in promoting innovative activities. In some regions, such as Silicon Valley, the development and commercialization of new technologies is supported by a vibrant venture capital industry. In other regions, such as Israel and Finland, the rise of a private venture capital industry has been preceded by deliberate government interventions. Indeed, in many countries where the promotion of innovative activities is a top policy priority, governmental funding agencies share objectives that are similar or comparable to those of private venture capital.

In this paper, we examine rationales relevant to the evolving roles of government intervention in the commercialization of new technologies. The motivation for explicating these rationales and their implications for innovation policy is that this may help design policy measures that realize potential complementarities with private venture capital while minimizing unwarranted interventions. At this juncture, the comments of Max Weber in Bureaucracy ${ }^{7}$ suggest a normative bias in favor of private venture capital:

Only the expert knowledge of private economic interest groups in the field of 'business' is superior to the expert knowledge of the bureaucracy. ... Very frequently the measures of the state in the field of capitalism take unforeseen and unintended courses, or they are made illusory by the superior expert knowledge of interest groups.

However, R\&D processes include interactions and feedback loops that are of limited interest to private venture capital. Thus, public support to those aspects that are ignored by the private venture capital industry may enhance the performance of innovation systems.

More specifically, we outline analytical perspectives - termed as rationales - for examining the role of government agencies in comparison with, or as a complement to, private venture capital. ${ }^{8}$ The first two rationales, market and systemic failure, take the institutional structure of the R\&D system as a given and attribute the production of non-optimal outputs to problems of appropriability and coordination, respectively. The third rationale, structural rigidities, examines the structure of the innovation system as a variable that is under limited political control. That is, changes initiated by policy-makers may persist long after the intervention due to the institutionalization of new practices. The fourth rationale, anticipatory myopia, proposes that individuals and organizations may underinvest in the generation and assimilation of information that contributes to their ability to act with foresight. Here, the role of the government intervention is to promote the identification and pursuit of new long-term opportunities.

The remainder of this paper is structured as follows. Section 2 discusses alternative roles of funding agencies in the commercialization of new technologies. Section 3 outlines rationales for government intervention, using Finland and Israel as practical examples. Section 4 discusses inherent problems in the government-agency relationship and the role of policy evaluation in mitigating these problems. Section 5 concludes the paper. 


\section{Background}

\section{(a) Innovation Systems}

Technological change is widely recognized as a key driver of economic development ${ }^{9}$ that to a considerable extent is driven by scientific and engineering efforts in the public and private sector. Furthermore, the very institutional structure of techno-economic interaction has changed: today, this structure is best depicted as a complex system that consists of universities, governmental research laboratories and legislative frameworks on intellectual property rights, as well as competition and cooperation among firms, among other things. These institutional structures have evolved in distinctive ways in different countries, as conveyed by the literature on 'national innovation systems'. ${ }^{10}$

Whilst systems that encourage or inhibit innovation are very complex, stylized models of innovation help in the analysis of specific institutions. Early on, Schumpeter ${ }^{11}$ divided economic activities into two broad categories.

(1) During the circular flow of economic life 'the economic system will not change capriciously on its own initiative but will be at all times connected with the preceding state of affairs'. ${ }^{12}$ The activities are based on previous experience, and the autonomous actors are coordinated by a price mechanism. ${ }^{13}$ The system may achieve incremental economic growth by the small adjustments taken at the margins, although the routines employed by firms remain the same. More radical changes (or 'development' as Schumpeter defined it), require that established rules are ignored and replaced by new combinations of activities.

(2) There are spontaneous and discontinuous changes in the economic system. As a result, different ways are used to combine materials and forces in the production process. Some new combinations are enabled by technological development (e.g. an introduction of a new production method), whereas others are predominately socioeconomic (e.g. organizational restructuring to break up a monopoly position). Often, these new combinations are not introduced by established firms but by new ones. ${ }^{14}$ Individuals who seek these new combinations are called 'entrepreneurs', who, if successful, create entrepreneurial profits 'to which no liability corresponds'. ${ }^{15}$

Entrepreneurial profits are temporary. New businesses emerge to gain a share of the profit opportunity - until what was new becomes routine and embedded in the industry equilibrium. Extraordinary profits are thus a result of successful change, suggesting that continuous extraordinary profits call for processes of continuous change-something that is quite unusual considering the proposed routine nature of the circular flow of economic activities. Established firms seek to enable these processes through industrial R\&D, while venture capitalists bear some of the financial risks that are inextricably linked to new entrepreneurial activities.

Industrial R\&D activities acquired a formal organizational form when the multidivisional, centrally coordinated manufacturing firms, such as DuPont and General Electric, rose into dominant industry positions in the early 20th century. The increasing coordination power of headquarters was associated with the establishment of corporate research centers. ${ }^{16}$ The corporate research centers had a dual role in internal inventive and external monitoring activities.

In the 1980s, however, especially US corporations perceived increasing competitive pressures and consequently 'externalized' some of their R\&D operations. ${ }^{17}$ Research joint ventures, strategic alliances and research consortia were widely established, making it 
possible to spread the costs of $\mathrm{R} \& \mathrm{D}$, to gain access to complementary capabilities, and to facilitate technology transfer. These changes were - and still are-manifest in certain high-technology industries, for example, biotechnology, where the locus of innovation has gradually moved from individual firms and research institutes to networks of innovators. ${ }^{18}$ Nevertheless, most industrial R\&D activities emphasized development rather than research, which caused policy concerns over the long-term rate of technological development. ${ }^{19}$

\section{(b) Funding Agencies for New Technology Development and Commercialization}

Industrial R\&D is 'the heart of capitalist engine' ${ }^{20}$ that drives techno-economic development and contributes to societal well-being. Venture capital industry is a part of the innovation system that is specialized in the commercialization of new technologies via start-up firms. Some countries have established agencies or initiatives with tasks comparable to those of the private venture capital. Examples include Small Business Innovation Research Program ${ }^{21}$ in the US, Sitra ${ }^{22}$ in Finland and Anvar ${ }^{23}$ in France. The specific tasks of the agencies, however, vary both across countries and time. Indeed, the developing roles of technology agencies can be conceived either as responses to observed deficiencies in the innovation system or as proactive measures to better realize its potential. The need for such a proactive stance towards future opportunities can be motivated by the fourth of our rationales, anticipatory myopia, which is discussed in the next section.

Governments have taken various policy measures to promote innovative activities in order to reap economic and social benefits from technological progress. ${ }^{24}$ One such measure is the establishment of agencies that provide selective funding for R\&D efforts in private firms, universities, and research institutes. ${ }^{25}$ Such funding is typically justified on the grounds that free market financing of $R \& D$ is not socially optimal. ${ }^{26}$ Most agencies provide funding on a per project basis, whereby the costs of $\mathrm{R} \& \mathrm{D}$ efforts are fully or partially subsidized.

In addition to providing selective funding for $\mathrm{R} \& \mathrm{D}$, the funding agencies may carry out other functions as well, for example, offer incubating services to small firms, distribute technological or market information, or activate firms to utilize the services of local research institutes. In general, however, the cost of these complementary services is small compared to the costs of providing financial support to even a moderate share of industrial R\&D efforts on the national scale. For the sake of analytical tractability, the following discussion of government intervention is mainly concerned with situations where the government takes an active part in the allocation of resources to R\&D.

In the next section, we discuss the above 'market failure' rationale, as well as other rationales, for government intervention in the commercialization of new technologies. To illustrate their practical ramifications, we also elaborate on some key innovation policy instruments deployed in two case countries, Finland ${ }^{27}$ and Israel, ${ }^{28}$ most notably Tekes' technology programs in Finland and the programs of the Office of Chief Scientist (OCS) in Israel. Both countries adopted a proactive stance towards innovation policy in the 1990s, and provided ample public support to R\&D activities through several instruments. In both countries, public support has apparently contributed to favorable economic development, as quantified by exports in high-technology industries or patent statistics, for example. Also, in both cases public initiatives preceded the substantial rise of private venture capital. Thus, although we cannot draw strong conclusions from stylized facts regarding the development of two specific innovation systems, such considerations illustrate areas from which more general lessons can be learned. 


\section{Rationales for Government Intervention}

\section{(a) Underinvestment in RED-Market Failure}

Arrow $^{29}$ showed that markets for information have uncomfortable properties. If there is no intellectual property protection, it is not feasible to sell information in the open market, as any buyer could reproduce and resell it at an insignificant cost. Moreover, a potential purchaser can determine the value of a piece of information only after receiving it, after which he has little need to pay for the information.

The information generated by $\mathrm{R} \& \mathrm{D}$ can be appropriated by a single firm only to a limited extent. Thus, in the absence of effective markets for information, profit-seeking firms are likely to invest in R\&D less than what would be socially optimal, and hence market failure occurs. ${ }^{30}$ To remedy the situation, the government can provide support for R\&D activities, especially for basic research in universities, research institutes and firms.

Firms conduct R\&D if they expect to benefit from the results through the sales of new products or cost savings due to more effective production processes, for example. Provided that there are no serious capital market imperfections, firms should be able to raise funds for $\mathrm{R} \& \mathrm{D}$ projects that they believe to be economically profitable. However, the results of $\mathrm{R} \& \mathrm{D}$ projects may also benefit other firms or the society at large. Market failure refers to the conditions under which the amount of funding allocated to R\&D by market forces is less than what is socially optimal. ${ }^{31}$

$\mathrm{R} \& \mathrm{D}$ activities can be viewed as a cumulative learning process where the assimilation of new knowledge is facilitated by previous complementary experiences. ${ }^{32}$ Thus, by undertaking R\&D firms not only produce new information but enhance their ability to recognize and utilize information that spills from the $R \& D$ activities of other firms, universities, and research institutes. ${ }^{33}$ The value of this absorptive capacity encourages firms to invest in research, especially in industries where scientific or technological change is rapid. ${ }^{34}$ This race to learn and invent may produce a socially optimal level of R\&D (or even exceed it), whereby government support would be justified mostly at the basic research end of the research-development continuum, where the potential spill-overs are most significant.

The market failure rationale is the foundation of several instruments of innovation policy, such as tax credits based on R\&D expenses. ${ }^{35}$ However, the rationale as such does not necessitate active governmental participation in the process of allocating resources to R\&D. Indeed, active participation is costly and also influences the behavior of those who conduct R\&D. Thus, instruments involving active governmental participation should induce desired changes in the behavior to offset the costs of intervention. Such changes could include, for instance, elements of quality control achieved via peer review that is one of the defining characteristics of basic research. ${ }^{36}$ In the commercialization of new technologies, however, the nature of the desired changes is more subtle because in their profit-seeking activities firms are presumably already doing their best, while the governments' track record in guiding commercialization efforts is rather mixed. ${ }^{37}$

In both Finland and Israel, the bulk of public support is provided via matched grants for project-specific R\&D expenses in companies. In Israel, the selection of supported projects does not involve prioritization between fields, as per the neutrality principle adopted by the OCS. ${ }^{38}$ In Finland, projects that fit into national technology programs have a comparative advantage, although such a fit is not a strict requirement. Thus, in both countries the intervention is not strongly aligned with narrowly defined mission-oriented research or attempts to set priorities among technological fields, but, rather, it is motivated as a correction of a market failure in general. Even in the case of Finnish technology programs, the priority-setting process is best described as that of facilitating discussions among 
public and private actors to demarcate common areas of collaborative R\&D efforts, rather than that of setting strict boundaries on areas that are eligible for support. ${ }^{39}$

\section{(b) Coordination Problems Among RED Participants-Systemic Failure}

Innovation systems can be viewed as a set of institutions whose interactions influence the innovative performance of the actors involved in R\&D. ${ }^{40}$ These actors include universities with basic research agendas, research institutes and corporate research centers conducting applied research, as well as firms that are active in product development and commercialization of new technologies. The working practices, incentives and priorities of these organizations support their primary tasks. If the practices, incentives and priorities are optimal at the level of individual organizations while the overall innovative performance of the system is sub-optimal, a systemic failure is said to be present. ${ }^{41}$

A linear view of the innovation process (in which scientific research, technological development and commercialization are regarded as sequential phases), ignores the complex feedback mechanisms that connect these parallel aspects of techno-economic development. ${ }^{42}$ That is, innovation is not only driven by research findings, but new promising research directions are often identified during the later phases of product development and commercialization. The effectiveness of the innovation system therefore depends on the interactions between firms, government laboratories, and universities. ${ }^{43}$ At the same time, the institutions, and the individuals that they employ, have distinctly different priorities that may inhibit collaboration. If the differences in priorities are significant enough to diminish the long-term performance of the innovation system, a systemic failure occurs. Here, the government can intervene by creating incentives that facilitate knowledge transfer between organizations in the different phases of innovation process, thus mitigating systemic failures in the commercialization of new technologies.

In many countries, technology programs where public and private participants pursue joint R\&D efforts ${ }^{44}$ have been launched as a policy response to partly mitigate this kind of systemic failure. ${ }^{45}$ Thus neither academic peer review (which would exclude the priorities of industry), nor unselective tax incentives (which would exclude the priorities of academia), are used as the primary resource allocation mechanisms. For example, in the technology programs of the National Technology Agency in Finland, administrative rules favor collaborative project proposals: for instance, projects proposed by universities are typically funded only if there is a participating industrial partner and large firms can receive more government support for projects that involve subcontracting from small firms or research institutes.

The proposed benefits of these collaborative efforts include the harmonization of incentive structures (in the sense that the academics are rewarded for industrially relevant work and the industry is encouraged to take part in R\&D activities at universities), joint prioritization of $\mathrm{R} \& \mathrm{D}$ goals and more intense interaction between the research and development ends of the R\&D continuum. ${ }^{46}$ The attainment of these benefits, however, involves several challenges, because technology programs have been criticized for rigid structures, premature selection of technological options, and consensus-seeking decisionmaking mechanisms. ${ }^{47}$

Systemic considerations do not fully explain how technology programs contribute to new Schumpeterian innovations, which require 'creative destruction' of established industry practices (e.g. use of biotechnology in pharmaceutical R\&D, or the transition from mainframes to personal computers). That is, if the emergence of new industries is associated with conflicts with established firms, closer university-industry collaboration may inhibit rather than promote $\mathrm{R} \& \mathrm{D}$ activities that threaten the technological or market 
positions of legitimate industrial sponsors. ${ }^{48}$ Consequently, the mechanisms of resource allocation should balance the interests of existing and potentially emerging firms and industries. To some extent, the latter may be disadvantaged, as established firms and industries have more political lobbying power. Owing to the discretion provided by civil servants, the interests of emerging industries may be represented by technology agencies, provided that their prevalent norms emphasize the exploratory nature of frontiers in technological and industrial development. Yet, to what extent the civil servants perceive and comply with such norms has received little empirical scrutiny. Emerging firms and industries can also be supported by interventions that specifically target them, as well as through funding procedures that specifically refer to the novelty criterion.

With regard to systemic failure, the practices in Finland and Israel differ. In Finland, systemic considerations are integrated directly into the technology programs. That is, research institutes and universities can typically submit project proposals to technology programs on condition that these proposals are supported by one or more industrial sponsors. . Also, firms are encouraged to establish subcontracts with universities in their research projects. In Israel, a separate initiative, the 'Magnet' program, supports the formation of consortia made of both industrial firms and academic institutions.

\section{(c) Inertia within Innovation Systems - Structural Rigidities}

Institutions, as well as technological expertise, develop through path-dependent processes. ${ }^{49}$ Institutional change is based predominately on continuous marginal adjustments, while external stimuli may provoke less gradual development paths. Insofar as the development of innovation systems is constrained by path-dependencies at the level of institutions or organizations, government interventions may stimulate new development paths. That is, innovation policies may seek to create variation and flexibility in the system to overcome potential structural rigidities.

The institutions in an innovation system are highly interdependent. For example, the venture capital industry in the Silicon Valley area in the US relies on specialized firms delivering legal services, close collaboration with local universities, and cultural norms that support the mobility of work force. ${ }^{50}$ As a consequence, if changes in one institution call for complementary changes in other institutions, the development of the system as a whole may be hampered even if only some of the institutions become rigid. New configurations in the evolutionary innovation system, as envisioned by Metcalfe, ${ }^{51}$ are unlikely to emerge without external stimuli. Thus, a government may launch experiments (support initiatives, or even direct organizational or institutional changes) to overcome structural rigidities. Moreover, if some experimental practices institutionalize and diffuse in the innovation system, such interventions can have significant long-term effects.

In the context of venture capital, governments have identified and initiated numerous policy measures, including direct supply of capital, financial incentives, and investor regulations, to support the growth of the private venture capital industry. ${ }^{52}$ For example, in 1990 there were only two private venture capital funds in Israel; but in 1993 the Israeli government invested US\$ 100 million in a venture capital fund with a focus on hightechnology start-up firms. By 1996, when the government sold its share of this fund, there were some 40 private venture capital funds specializing in technology-based firms. It is plausible that the government's intervention (temporary support of novel means to commercialize new technologies) contributed to the development of an institutional environment in which the private venture capital industry could finally prosper on its own.

Technological progress often follows 'paradigms', ${ }^{53}$ and organizations accrue specialized expertise relevant to these major development paths. The stock of expertise limits 
the set of feasible future R\&D project options. If there is a certain minimum 'critical mass' for activities that aim to develop new areas of expertise, instruments such as technology programs may subsidize part of the set-up costs and activate other potential participants. Thus, active government participation in the allocation of resources for R\&D would be concentrated on emerging technologies. Arguably, such interventions would contribute to the renewal of expertise pools in R\&D organizations, which in turn would expand the number of directions the innovation system could pursue on its own. From this perspective, a government intervention could be motivated as a temporary measure to reconfigure the innovation system. More generally, if reconfigurations are typical to successful innovation policies, then the government's ability to identify and initiate new policy experiments would be important. ${ }^{54}$

Among the interventions that aim to correct a structural rigidity, the above-mentioned Israeli 'Yozma' initiative to jump-start the venture capital market is noteworthy. The initiative was timely but short-lived, i.e. it purposely served a transitory role in the innovation system. In Finland, technology programs also have limited life-spans of typically three to five years. Thus, although the institutional changes pursued in the programs are less drastic than in Yozma (i.e. the goals typically involve strengthening of collaboration clusters across organizations), the programs do promote temporary reconfigurations in the innovation system.

\section{(d) Anticipatory Myopia}

Successful interventions based on the preceding rationale, structural rigidities, require that policy makers have a good understanding of what kinds of experiments and policy measures are called for and what impacts these are likely to have. However, to the extent that actors in the innovation system do not attempt to foresee beneficial intervention opportunities, or do not act on the insights they possess, the innovation system may suffer from anticipatory myopia. Here, anticipatory myopia is not limited to governmental agencies, as both public and private organizations may adopt a reactive stance (as opposed to a proactive one) vis-à-vis future opportunities. ${ }^{55}$ This is all the more so, because none of the actors alone may be able to change conditions that apply across organizational or institutional boundaries. Hence, responses to anticipatory myopia are likely to call for interventions that seek to abolish identified structural rigidities.

There are several dimensions to anticipatory myopia. First, information about future opportunities is expensive to acquire and hard to trade or appropriate. Thus, analogously to the market failure associated with the intensity of $\mathrm{R} \& \mathrm{D}$ efforts as such, actors may under invest in foresight activities. ${ }^{56}$ Second, the actors that have information of future opportunities may not be the ones to act on it. Thus, in the absence of incentives that support collaboration across organizational boundaries, even foresight information that is otherwise be actionable may remain unused; this parallels the systemic failure. Third, even if an actor possesses actionable foresight information, the implementation of an experiment may require collaboration with other organizations or complementary institutional changes. Thus, structural inertia may inhibit experimentation.

Public and private organizations differ in several key dimensions, including incentive intensity, administrative controls and adaptation characteristics. ${ }^{57}$ Because these differences are likely to affect the behavior of public and private organizations, both should be promoted in performing tasks in which they have comparative efficiency advantage. More often than not, the incentives of civil servants are not strongly dependent on the outcome of the R\&D projects that they choose to fund. In contrast, the general partners of private venture capital funds typically receive $15-25 \%$ of the capital gains generated 
by their fund. ${ }^{5}$ Thus, other things being equal, it is plausible that private venture capitalists have stronger incentives to spend more time and effort in the initial decision making and later monitoring of ventures. However, the close scrutiny of R\&D projects by venture capitalists may not directly be applicable to settings in which the projects mitigate systemic failures (e.g. university-industry collaboration with compromise goals) or structural rigidities (e.g. development of new expertise pools of uncertain commercial appropriateness). That is, while the venture capitalists have strong incentives to maximize the economic success of the projects that they fund and monitor, any other concerns of systemic failures or structural rigidities are secondary and likely to receive little attention.

For example, Lerner ${ }^{59}$ found that the Small Business Innovation Research (SBIR) program, a major US public venture capital initiative, had a strong positive impact only on those firms that operated in geographic areas with active private venture capital, and the beneficial effect was greatest for firms in industries that did not frequently attract funding from sources of private venture capital. This suggests that civil servants are able to select firms with growth potential in a wide variety of industries, yet private venture capital, or associated business infrastructure, is needed to realize that potential. The explanation concurs with the stylized fact that the private venture capital industry tends to focus on select 'hot' technologies. To mitigate anticipatory myopia, technology agencies could fund a broad variety of start-up firms, whereas the private venture capital would commit to the most promising opportunities and ensure that these receive resources for expansion.

Trajtenberg summarized the Israeli experience by proposing that if the institutional setting does not allow for a speedy process of adaptation and innovation in policy design, it may be better not to intervene to begin with'. ${ }^{60}$ Salo and Salmenkaita ${ }^{61}$ argued that the Finnish technology programs have elements that provide 'embedded foresight'. Indeed, it seems plausible that the organizational conditions provided by OCS and Tekes have reduced anticipatory myopia in the innovation systems. As an example, the technology experts (civil servants) of Finnish National Technology Agency review tens of project proposals by firms, research institutes and universities in a given technology area per year. In the process of following approved projects, they develop long-term ties to the respective R\&D groups. Senior technology experts also have an important role in facilitating the preparation of new technology programs.

\section{(e) Summary of Rationales}

The four rationales for intervention are summarized in Table 1. In addition to examples and diagnoses, corresponding challenges for evaluation are also emphasized. Specifically, to correct market failure, resources are provided to ensure the desired quality and quantity of R\&D outputs, whereby the mechanisms of priority setting and the productivity of $\mathrm{R} \& \mathrm{D}$ process are scrutinized. The rationale of systemic failure, on the other hand, calls for measures that are geared towards the promotion of collaboration networks. If the intervention seeks to change the structure of the innovation system by overcoming structural inertia, the evaluation of success involves the comparison to the counterfactual development of the system with and without intervention (i.e. in view of the uniqueness of innovation systems, it is not possible to make a direct comparison between a system that has been subjected to an intervention and a system that has developed gradually). Intervention to mitigate anticipatory myopia relies, at least implicitly, on distinguishing activities of varying levels of forward-looking exploration. Here, interventions could seek to facilitate processes that help generate foresight. ${ }^{62}$ Given these challenges, it is plausible that the effectiveness of 'higher-order' interventions may remain rather equivocal. 
Table 1. Summary of policy rationales

\begin{tabular}{|c|c|c|c|}
\hline & Examples of intervention & Diagnosis & Evaluation challenge \\
\hline Market failure & $\begin{array}{l}\text { Support university research in } \\
\text { specific fields }\end{array}$ & $\begin{array}{l}\text { Technological/scientific } \\
\text { fields critical for future } \\
\text { competitiveness do not } \\
\text { receive adequate resources }\end{array}$ & $\begin{array}{l}\text { Appropriate level of resources } \\
\text { for different fields (priority } \\
\text { setting); Quality and quantity } \\
\text { of R\&D (outputs) }\end{array}$ \\
\hline Systemic failure & $\begin{array}{l}\text { Support university-industry } \\
\text { collaborative projects }\end{array}$ & $\begin{array}{l}\text { Existing } \mathrm{R} \& \mathrm{D} \text { capabilities } \\
\text { are not utilized effectively }\end{array}$ & $\begin{array}{l}\text { Quantification of benefits and } \\
\text { drawbacks related to } \\
\text { collaboration networks }\end{array}$ \\
\hline Structural inertia & $\begin{array}{l}\text { Provide public venture capital } \\
\text { when private VC is non-existent; } \\
\text { Create a system of 'centers of } \\
\text { excellence' to both renew and } \\
\text { strengthen collaboration clusters }\end{array}$ & $\begin{array}{l}\text { Pursuit of new opportunities } \\
\text { is seriously constrained by } \\
\text { status quo }\end{array}$ & $\begin{array}{l}\text { Comparison between } \\
\text { counterfactual development of } \\
\text { the system without } \\
\text { intervention }\end{array}$ \\
\hline $\begin{array}{l}\text { Anticipatory } \\
\text { myopia }\end{array}$ & $\begin{array}{l}\text { Create joint decision-making } \\
\text { situations among government, } \\
\text { industry, and university } \\
\text { representatives }\end{array}$ & $\begin{array}{l}\text { Insights are not acted upon; } \\
\text { Experimentation follows } \\
\text { herd behavior }\end{array}$ & $\begin{array}{l}\text { Quantification of exploratory } \\
\text { nature of actions; } \\
\text { Understanding of processes } \\
\text { that generate foresight }\end{array}$ \\
\hline
\end{tabular}

\section{Perspectives on Normative Rationales for Intervention}

In order to realize the benefits associated with the interventions called for by the four rationales, a funding agency must constantly re-invent itself, not least because any fixed set of activities will become sub-optimal in the long run as the innovation system keeps on evolving. This notwithstanding, information asymmetries in the political system may foster policy interventions even in situations where this does not engender social welfare benefits; we refer to this as 'policy capture'. Specifically, we identify factors that may give rise to policy capture and then discuss considerations that may help technology agencies to successfully re-invent their activities. Because these factors and considerations do overlap, different kinds of policy evaluation are highlighted as a partial solution to this dilemma.

\section{(a) Policy Capture}

Innovation is a complex and uncertain process, affected by the institutional environment, national policies and firm-specific characteristics. Despite the challenges in the identification of effective policy measures, political actors may be rewarded for being perceived as 'pro-innovation'. Thus, due to bounded rationality considerations, policy experiments can be undertaken even in the absence of a clear causal rationale. ${ }^{63}$ Experiments provide new information that can be used to gradually refine the policies. A funding agency can therefore be seen as an enabler of policy experiments, or an organization that facilitates control, accumulation of experience and even accountability.

Organizations, however, tend to develop purposes of their own. ${ }^{64}$ To exist, they require an inflow of resources that maintains the internal incentive equilibrium, ${ }^{65}$ andto receive the resources - the organization has to respond to external demands. A funding agency, for example, receives financial resources from the government and allocates them to universities, research institutes and firms. From this perspective, the agency fulfills politicians demand for 'pro-innovativeness' if it (and thus indirectly the politicians) receives public credit and recognition from universities, research institutes and firms. From the viewpoint of recipients of funding, public credit and recognition is a relatively low cost way to enhance the likelihood of receiving more financial support. As a result, 
the agency can be captured in a reinforcing process of political recognition, where the allocation of resources may be unduly influenced by the desire to enhance public recognition as a step towards the reception of further resources. Such a process may become problematic, if the quest for public recognition deserves undue attention as a motive for resource allocation.

Political recognition is sustainable only if stakeholder groups are not able to collect verifiable information on the relative (in)effectiveness of the activities supported by the agency. ${ }^{66}$ Indeed, in the case of public support for private R\&D, factors such as confidentiality concerns, time lags and ambiguous performance criteria make the collection of verifiable information a challenging task. Moreover, if the agency has considerable autonomy in designing its activities, it is difficult to impose procedural rules to ensure multiple interest group participation. ${ }^{67}$ In the extreme, if the agency is fully autonomous in designing its operations, it may control its own evaluation procedures and, in the extreme, provide selective information on the effectiveness of its operations. Thus, positive feedback and recognition is ensured, and the polity remains content. To overcome the risk of policy capture, the agencies can deploy transparent evaluation procedures, as well as methods for exposition of various stakeholders' viewpoints.

\section{(b) Neutral Competence Requirements}

Successful agency operations require a high level of expertise. The adjacent tasksdetermination of socially optimal levels of investment in $R \& D$ in various fields, correction of incentive mismatches between R\&D organizations, design of policy initiatives for the reconfiguration of the national innovation system, as well as the identification of $\mathrm{R} \& \mathrm{D}$ opportunities that enable new industries to emerge - stretch the limits of bounded rationality even under the most favorable conditions. At the minimum, these tasks require 'neutral competence', experienced civil servants with professional careers. ${ }^{68}$

Funding agencies are controlled by public authority. By its very nature, public authority is coercive, as winning political coalitions impose their will on others. ${ }^{69}$ The structure of public institutions reflects political uncertainty, compromise and protection against unanticipated exercise of authority, which may undermine the agency's performance in its core tasks. Legislation and procedural rules can be used to define the mandate of the agency, the extent and mode of interest group participation, and attendant activities of an agency, thereby increasing political control over it. Such restrictions partly constrain the agency's ability to solve complex problems by internal coalition formation ${ }^{70}$ and to accumulate organizational knowledge generated through new activity patterns. ${ }^{71}$

In view of the above, governments are faced with a control-effectiveness trade-off in the authorization and management of funding agencies. If the primary goal is to achieve effectiveness in executing operational tasks, the agency should be a politically insulated, autonomous entity, able to reconfigure its activities according to accumulating experience. Then, however, information asymmetries between the government and the agency tend to increase while control decreases - conditions in which activities in 'policy capture' mode, with weaker connections to actual effectiveness, may flourish. In practice, the requirements for control and neutral competence must be balanced so that the agencies have an interest to propose new solutions.

\section{(c) Embeddedness Requirements}

The tasks of technology agencies require a wide variety of information on the state-ofthe-art in science and technology, market development and the capabilities of local R\&D 
organizations. Here, primary sources of information include the very organizations that the agency is funding - universities, research institutes and private firms. By being tightly embedded in the local innovation system, the agency is able to gather information (including informal opinions about technological and market trends) that is relevant to its decision making processes. Embeddedness, however, may lead to the loss of impartiality, or eventual collusion, between the agency and other organizations in the local innovation system. $^{72}$ Thus, while embeddedness (and the use of informal information in decision making) enhances the agency's decision making capabilities, it also increases the risk of the 'policy capture' mode of operation.

If the agency controls its own agenda, embeddedness will have an effect on the initiatives that it chooses to undertake. Ocasio ${ }^{73}$ has presented a synthesis of the mechanisms controlling attention in organizations, identifying how decision-making outcomes depend on the decision-making environment. The underlying theme is that information is equivocal and that the same information can lead to different actions due to decision makers' selective attention and contextual differences. ${ }^{74}$ The agency's collaborative relations and associated information sources thus frame how new opportunities and courses of action are perceived. At worst, these biases can be harmful if the agency is expected to represent both existing and emerging areas of R\&D activity in its resource allocation decisions.

Thus, governments authorizing technology agencies face a trade-off between information richness and bias. If the primary goal is to exploit a wide array of information sources in the agency's decision making processes, the agency should be embedded in the national innovation system. Then, information asymmetries between the government and the agency, as well as the risk of collusion, increase, giving rise to conditions that may be favorable to the 'policy capture' mode of operation.

\section{(d) Role of Evaluation as an Adaptable Control Instrument}

The above trade-offs between (1) control and effectiveness, and (2) information richness and bias, call for practices that mitigate information asymmetries while preserving the autonomy that is required to carry out reconfigurations to support organizational learning. In the area of technology policy, evaluation of policy measures has received increasing attention. ${ }^{75}$ The usual definition of evaluation - 'the analysis and assessment of technology policy goals, instruments, and impacts ${ }^{76}$ — implies that evaluations cover both the rationales for action and the chains of events caused by the intervention. However, comprehensive evaluations may be unfeasible if the rationales remain equivocal or the causal chains are exceedingly complex. Even so, series of evaluations with a more limited scope may serve as a control for policy capture.

By distinguishing different types of evaluation, it is possible to outline realistic aims for each. Ex ante evaluations explicate rationales for government intervention; constructive evaluations aim to enhance ongoing interventions by synthesising perspectives from the different stakeholders; and ex post evaluations are typically analytic exercises that trace the impacts of past interventions.

Even though these three types of evaluation are concerned with policy goals, instruments and impacts, the learning mode in each is different. By combining the three types of evaluation into a sequence, the government can mitigate the risk of activities in 'policy capture' mode while letting the agency operate in an autonomous and embedded manner. In Finland, for example, evaluations of technology programs are routinely commissioned from external parties; in effect, they have become a routine aspect of innovation policy practice. ${ }^{77}$ 
Ex ante evaluations provide insight into intervention alternatives. The rationale for intervention is explicated, alternative actions are considered, relevant performance indicators are identified and baseline data is collected. If an agency possesses neutral competence to initiate interventions in the innovation system, ex ante evaluation formalizes the beginning of the intervention process. Ideally, the early identification of performance indicators and baseline data prevents retrospective rationalization of activities, and reduces the agency's ability to provide selective information on positive effects only. $E x$ ante evaluations are anticipatory, as milestones, scenarios, or roadmaps can be used to lend structure to the cognitive exercise. ${ }^{78}$ Overall, the goal is to develop and communicate a story of what tasks should be carried out in order to prepare for the future.

From the perspective of neutral competence, the agency itself is capable of carrying out $e x$ ante evaluations. The competence to identify promising paths of action resides in the networks between the agency, universities, research institutes and firms. Ex ante evaluation reflects some stakeholders' desired future state, whereby the role of government is to define boundary conditions for policy interventions and to set priorities for interventions. Because evaluation initiates these policy discussions it serves the 'futureorientation' that has been credited to technology foresight exercises as well. ${ }^{79}$ Evaluation professionals can support ex ante evaluations by providing examples of suitable performance metrics (e.g. impact-weighted publications in specific scientific area, or ratio of start-up firms to public R\&D spending).

Constructive evaluations are reviews of on-going interventions. They may include both outward and inward-looking elements. A given intervention can be compared to similar interventions in other contexts, thus identifying either emerging best practices or complementary activities. Specifically, constructive evaluations can synthesize both actual and potential (or excluded) stakeholders' perspectives on the intervention. Thus, the agency is less able to control information on the effectiveness of its activities and 'policy capture' mode activities can be identified. For this purpose, the performance metrics and baseline data defined in ex ante evaluations are essential.

Professional evaluators have a critical role in constructive evaluations. They should be perceived as neutral by the government, the agency and other stakeholders. The evaluations should be commissioned in a way that facilitates impartiality. Nevertheless, close collaboration with the agency may be warranted to provide direct operational feedback to the agency.

Among other things, ex post evaluations review the impacts of past interventions. Micro-economic research may be useful in this role, although a specific evaluation can be justified if the evaluation is to produce policy guidelines beyond the scope of academic research. Evaluators may also help the agency to produce a more objective 'lessons learned' analysis for its internal use.

Ex ante, constructive, and ex post evaluations form a continuum in time. The evaluators, agency, government and academics have complementary roles in specific evaluation projects that may draw upon different characteristics from these three archetypal evaluations, depending on the specific objectives and context of the project. Overall, ex ante evaluations have to be performed where the competencies are, constructive evaluations benefit from neutral third party evaluators and ex post analysis should follow the research practices of relevant scientific disciplines (e.g. microeconomics and innovation studies). These differences are summarized in Table 2.

\section{Conclusions}

In this paper, we have investigated alternative reasons and related challenges for policy 
Table 2. Role of evaluation in policy development

\begin{tabular}{|c|c|c|c|c|}
\hline & & Ex ante & Constructive & Ex post \\
\hline (1) & $\begin{array}{c}\text { Rationale } \\
\text { - GOAL }\end{array}$ & $\begin{array}{l}\text { Explicate the rationale for } \\
\text { intervention (agency/ } \\
\text { government) }\end{array}$ & $\begin{array}{l}\text { Compare to other similar } \\
\text { interventions (evaluator) }\end{array}$ & $\begin{array}{l}\text { Generalize results into policy } \\
\text { guidelines (government/ } \\
\text { evaluator/academics) }\end{array}$ \\
\hline (2) & $\begin{array}{l}\text { Implementation } \\
\text {-INSTRUMENT }\end{array}$ & $\begin{array}{l}\text { Compare proposed actions } \\
\text { to other feasible ones (agency) }\end{array}$ & $\begin{array}{l}\text { Initiate complementary } \\
\text { actions (evaluator/government) }\end{array}$ & $\begin{array}{l}\text { Compare the impacts to } \\
\text { those of competing } \\
\text { instruments (evaluator/ } \\
\text { academics) }\end{array}$ \\
\hline (3) & $\begin{array}{l}\text { Performance } \\
\text { measures } \\
\text {-IMPACT }\end{array}$ & $\begin{array}{l}\text { Identify performance metrics } \\
\text { and collect baseline data } \\
\text { (agency/evaluator) }\end{array}$ & $\begin{array}{l}\text { Review performance metrics, } \\
\text { ensure data collection, and } \\
\text { provide operational feedback } \\
\text { (evaluator/agency) }\end{array}$ & $\begin{array}{l}\text { Analyze the effectiveness of } \\
\text { actions (evaluator/academics) }\end{array}$ \\
\hline & Learning mode & $\begin{array}{l}\text { Anticipatory: Outline } \\
\text { milestones, scenarios, or } \\
\text { roadmaps to achieve goals } \\
\text { (agency) }\end{array}$ & $\begin{array}{l}\text { Synthetic: Compare } \\
\text { stakeholders' perspectives } \\
\text { (evaluator) }\end{array}$ & $\begin{array}{l}\text { Analytic: Perform lessons } \\
\text { learned - analysis (agency/ } \\
\text { evaluator) }\end{array}$ \\
\hline
\end{tabular}

intervention in the commercialization of new technologies. In particular, four rationales for government intervention in commercialization processes were identified and analyzed:

(1) Due to appropriateness problems, private markets may invest less than what is socially optimal in R\&D. This rationale, when taken in isolation, does not call for the appraisal of project proposals by technology agencies (or for peer review-based decision-making mechanisms), nor does it necessitate support for R\&D conducted by firms instead of universities.

(2) Public intervention through selective subsidies may mitigate systemic failure by creating incentives that encourage collaboration between universities, research institutes and firms. There is a possibility, however, that public interventions based on this rationale may favor $\mathrm{R} \& \mathrm{D}$ activities in established rather than emerging industries.

(3) Public interventions may counteract structural rigidities by encouraging temporary re-configurations of the innovation system, thus fostering the development of new self-sustaining patterns of activity, including the creation of new areas of expertise within R\&D organizations.

(4) Despite their complementary roles, technology agencies and the private venture capital industry may suffer from anticipatory myopia in that they devote insufficient resources to the identification and pursuit of long-term opportunities, partly due to differences in their incentives, information sources and propensity to opportunistic behavior. Here, public interventions may be designed to foster foresight via publicprivate joint activities, for instance.

Selected policy instruments, or even institutional structures related to agency operations, may continue to be supported due to high information asymmetries; this mode was referred to as 'policy capture'. To succeed in its operations (i.e. presuming the agency is not in the 'policy capture' mode), the agency requires internal expertise and access to a wide variety of information. It is paradoxical that while autonomy is likely to contribute to the development of expertise, it may decrease the government's ability to detect 'policy capture' mode activities. Also, embeddedness in the innovation system supports information acquisition, but increases the risk of collusion in 'policy capture' mode activities. Different kinds of policy evaluation - ex ante, constructive, and ex post - help mitigate these perplexing dilemmas. 
To summarize, active government participation in the allocation of resources for R\&D should not be viewed narrowly as a task of establishing priorities for projects or technological fields. Rather, there is a need for participatory activities that allow the government to recognize different rationales for its intervention and to take systemic considerations into account. Here, there are close parallels to technology foresight that, as an instrument, raise the general awareness of new opportunities and help reduce counterproductive inertia by suggesting innovative policy instruments.

Further research, for example case studies of funding agencies, should uncover the relative importance of the rationales we have outlined. Quantitative studies, following the examples set by Lerner, ${ }^{80}$ and Kortum and Lerner, ${ }^{81}$ should analyze the comparative effectiveness of private and public solutions, assuming that their goals are indeed competing or complementary. However, we believe that the conceptual clarification of the four rationales and their relationships to different forms of evaluation practices facilitates the development of appropriate policy measures.

\section{Notes and References}

1. E.g. National Bureau of Economic Research, The Rate and Direction of Inventive Activity: Economic and Social Factors (Princeton, Princeton University Press, 1962); C. Freeman \& L. Soete, The Economics of Industrial Innovation, 3rd edn (London, Pinter, 1997).

2. E.g. S.J. Kline \& N. Rosenberg, 'An Overview of Innovation', in: R. Landau \& N. Rosenberg (Eds), The Positive Sum Strategy: Harnessing Technology for Economic Growth (Washington, D.C., National Academy Press, 1986), pp. 275-305.

3. E.g. R.R. Nelson (Ed.), National Innovation Systems: A Comparative Analysis (Oxford, Oxford University Press, 1993).

4. E.g. K. Pavitt \& W. Walker, 'Government Policies Towards Industrial Innovation: A Review', Research Policy, 5, 1976, pp. 11-97; D.C. Mowery 'The Practice of Technology Policy', in: P. Stoneman (Ed.), Handbook of the Economics of Innovation and Technological Change (Oxford, Blackwell, 1995), pp. 513-557; OECD, 'New Rationale and Approaches in Technology and Innovation Policy', STI Review, 22 (Paris, Organisation for Economic Co-operation and Development, 1998).

5. T. Andersson, 'Managing a Systems Approach to Technology and Innovation Policy', in: OECD, ibid., pp. 9-29.

6. Mowery, op. cit., Ref. 4, p. 514.

7. H.H. Gerth \& C.W. Mills (Eds), From Max Weber: Essays in Sociology (New York, Oxford University Press, 1946), p. 235.

8. One might stylize governments as intervening more or less extensively in the new technology commercialization process, which thus creates a dichotomy of 'free-market-government intervention' policies, for example, US vs. European style, cf. S. Giesecke, 'The Contrasting Roles of Government in the Development of Biotechnology Industry in the US and Germany', Research Policy, 29(2), 2000, 205-223. However, the actual policy practices are much more complicated: Lerner, for example, identified 25 public US venture capital initiatives, including at least 43 state venture funds. J. Lerner, 'The Government as Venture Capitalist: The Long-run Impact of the SBIR Program', NBER Working Paper Series No. 5753, 1996, pp. 31-32.

9. Freeman \& Soete, op. cit., Ref. 1.

10. Nelson, op. cit., Ref. 3.

11. J.A. Schumpeter, The Theory of Economic Development (Cambridge, MA, Harvard University Press, 1934).

12. Ibid., p. 9.

13. F.A. Hayek, 'The Use of Knowledge in Society', The American Economic Review, 35(4), 1945, pp. 519-530.

14. Schumpeter, op. cit., Ref. 11, p. 66.

15. Ibid., p. 132. 
16. D.C. Mowery, 'The Development of Industrial Research in U.S. Manufacturing', American Economic Reviere, $80(2)$, 1990, pp. 345-349.

17. D.C. Mowery, 'The Changing Structure of the US National Innovation System: Implications for International Conflict and Cooperation in R\&D Policy', Research Policy, 27(6), 1998, pp. 639-654.

18. W.W. Powell, K.W. Koput \& L. SmithDoerr, 'Interorganizational Collaboration and the Locus of Innovation: Networks of Learning in Biotechnology', Administrative Science Quarterly, 41(1), 1996, pp. 116-145.

19. R.R. Nelson \& P.M. Romer, 'Science, Economic Growth, and Public Policy', Challenge, 39(2), 1996, pp. 9-21; OECD, 'Managing the Science Base', in: Technology, Productivity and Fob Creation-Best Policy Practices (Paris, Organisation for Economic Co-operation and Development, 1998).

20. R.R. Nelson, The Sources of Economic Growth (Cambridge, MA, Harvard University Press, 1996).

21. http://www.sba.gov/SBIR/sbir.html.

22. http://www.sitra.fi/.

23. http://www.anvar.fr/.

24. OECD, National Innovation Systems (Paris, Organisation for Economic Co-operation and Development, 1997).

25. For European agencies, see http://www.taftie.org/. Small Business Innovation Research (SBIR) Program, http://www.sba.gov/SBIR/sbir.html, has a somewhat similar role in the US.

26. E.g. TAFTIE, TAFTIE Guidelines on Performance Indicators for Evaluation and Monitoring (TAFTIE Evaluation Network, 1997).

27. E.g. A. Salo, K. Pahlavan \& J.-P. Salmenkaita, RED Programmes in Electronics and Telecommunication: ETX, TLX, INWITE and Telectronics (Helsinki, Tekes, 2000); E. Tuomaala, S. Raak, E. Kaukonen, J. Laaksonen, M. Nieminen \& P. Berg, Research and Technology Programme Activities in Finland (Helsinki, Tekes, 2001).

28. E.g. M. Trajtenberg, 'R\&D Policy in Israel: An Overview and Reassessment', NBER Working Paper Series No. 7930, 2000; M. Trajtenberg, 'Government Support for Commercial R\&D: Lessons from the Israeli Experience', NBER Conference on Innovation Policy and the Economy, Washington, 17 April 2001.

29. K.J. Arrow, 'Economic Welfare and the Allocation of Resources for Invention', in: K.J. Arrow (Ed.), Essays in the Theory of Risk-bearing (Amsterdam, North-Holland, 1970), pp. 144-163.

30. R.R. Nelson, 'The Simple Economics of Basic Scientific Research', The fournal of Political Economy, 67(3), 1959, pp. 297-306.

31. E.g. Arrow, op.cit., Ref. 29.

32. M. Polanyi, Personal Knowledge: Towards a Post-critical Philosophy (Chicago, University of Chicago Press, 1958).

33. W.M. Cohen \& D.A. Levinthal, 'Absorptive Capacity: A New Perspective on Learning and Innovation', Administrative Science Quarterly, 35(1), 1990, pp. 128-152.

34. W.M. Cohen \& D.A. Levinthal, 'Innovation and Learning: The Two Faces of R\&D', The Economic Fournal, 99(397), 1989, pp. 569-596.

35. E.g. B. Hall \& J. Van Reenen, 'How Effective are Fiscal Incentives for R\&D? A Review of the Evidence', Research Policy, 29(4-5), 2000, pp. 449-469.

36. For example, in the Finnish context the resource allocation decisions by National Technology Agency, http://www.tekes.fi/, are based on selective expert (government civil servant) assessment, whereas the Academy of Finland, http://www.aka.fi/, primarily uses peer review.

37. E.g. R.R. Nelson, 'Capitalism as an Engine of Progress', Research Policy, 19, 1990, pp. 193-214.

38. Trajtenberg, op. cit., Ref. 28.

39. Cf. A. Salo \& J.-P. Salmenkaita, 'Embedded Foresight in RTD Programs', International Fournal of Technology, Policy, and Management, forthcoming, 2002.

40. Nelson, op. cit., Ref. 20, p. 276.

41. Cf. Andersson, op. cit., Ref 5. 'Systems of innovation' can be analyzed, for example, from evolutionary, institutional, and learning perspectives, e.g. C. Edquist (Ed.), Systems of innovation: Technologies, Organizations, and Institutions (London, Pinter, 1997); S. Metcalfe, 'The Economic Foundations of Technology Policy: Equilibrium and Evolutionary Perspectives', in: P. Stoneman (Ed.), Handbook of the Economics of Innovation and Technological Change (Oxford, Blackwell, 1995), pp. 409-512; Nelson, op. cit., Ref. 20. Accordingly, the definitions of the potential sources of failure 
vary. The definition used in this paper is rather narrow, excluding for example some demand-side considerations. However, the structural rigidity and anticipatory myopia rationales will expand our analysis of the different sources of failure.

42. Kline \& Rosenberg, op. cit., Ref. 2.

43. J.S. Metcalfe \& L. Georghiou, 'Equilibrium and Evolutionary Foundations of Technology Policy', in: OECD, op. cit., Ref. 4., pp. 75-100.

44. OECD, 'Public/Private Partnerships in Science and Technology', STI Revierw, 23 (Paris, Organisation for Economic Co-operation and Development, 1998).

45. For example, European Union Fifth Framework Programme (FP5), http://www.cordis.lu/fp5/ home.html.

46. Cf. T.J. Buisseret, H.M. Cameron \& L. Georghiou, "What Difference Does it Make?” Additionality in the Public Support of R\&D in Large Firms', International Fournal of Technology Management, 10(5/ 6), 1995, pp. 587-600.

47. T. Luukkonen, 'The Difficulties in Assessing the Impact of EU Framework Programmes', Research Policy, 27(6), 1998, pp. 599-610.

48. Cf. H.E. Aldrich \& C.M. Fiol, 'Fools Rush in? The Institutional Context of Industry Creation', Academy of Management Review, 19(4), 1994, pp. 645-670.

49. D.C. North, Institutions, Institutional Change and Economic Performance (Cambridge, Cambridge University Press, 1990).

50. A.L. Saxenian, 'The Origins and Dynamics of Production Networks in Silicon Valley', Research Policy, 20(5), 1991, pp. 423-437.

51. Metcalfe, op. cit., Ref. 41.

52. OECD, Government Venture Capital for Technology-based Firms (Paris, Organisation for Economic Cooperation and Development, 1997).

53. G. Dosi, 'Technological Paradigms and Technological Trajectories: A Suggested Interpretation of the Determinants and Directions of Technical Change', Research Policy, 11(3), 1982, pp. 147-162.

54. E. Ormala, 'New Approaches in Technology Policy: The Finnish Example', in: OECD, op. cit., Ref. 4, pp. 277-283.

55. Cf. A.A. Salo, 'Incentives in Technology Foresight', International fournal of Technology Management, 21(7-8), 2001, pp. 694-710.

56. For examples of formal foresight exercises, see B.R. Martin, 'Technology Foresight: A Review of Recent Government Exercises', STI Review, 17, 1996, pp. 15-50; for discussion of foresight activities embedded in technology programs, see Salo \& Salmenkaita, op. cit., Ref. 39.

57. O.E. Williamson, 'Public and Private Bureaucracies: A Transaction Cost Economic Perspective', The Fournal of Law, Economics, \& Organization, 15(1), 1999, pp. 306-342.

58. P.A. Gompers \& J. Lerner, The Venture Capital Cycle (Cambridge, MA, MIT Press, 1999).

59. Lerner, op. cit., Ref. 8.

60. Trajtenberg (2001), op. cit., Ref. 28, p. 47.

61. Salo \& Salmenkaita, op. cit., Ref. 39.

62. Ibid.

63. G.E. Lindblom, The Intelligence of Democracy: Decision Making Through Mutual Adjustment (New York, Free Press, 1965).

64. P. Selznick, Leadership in Administration: A Sociological Interpretation (New York, Harper and Row, 1957).

65. C.I. Barnard, The Functions of The Executive (Cambridge, MA, Harvard University Press, 1938).

66. R.J.P. de Figueiredo, Jr, P.T. Spiller \& S. Urbiztondo, 'An Informational Perspective on Administrative Procedures', The Fournal of Law, Economics, \& Organization, 15(1), 1999, pp. 283-305.

67. M.D. McCubbins, R.G. Noll \& B.R. Weingast, 'Administrative Procedures as Instrument of Political Control', The Journal of Law, Economics, \& Organization, 3(2), 1987, pp. 243-277.

68. T.M. Moe \& M. Caldwell, 'The Institutional Foundations of Democratic Government: A Comparison of Presidential and Parliamentary Systems', Journal of Institutional and Theoretical Economics, 150(1), 1994, pp. 171-195.

69. T.M. Moe, 'Politics and the Theory of Organization', Fournal of Law, Economics, \& Organization, 7 , 1991, pp. 106-129.

70. R.M. Cyert \& J.G. March, A Behavior Theory of The Firm (Englewood Cliffs, NJ, Prentice-Hall, 1963). 


\section{7.-P. Salmenkaita \& A. Salo}

71. D.J. Teece, G. Pisano \& A. Shuen, 'Dynamic Capabilities and Strategic Management', Strategic Management Journal, 18(7), 1997, pp. 509-533.

72. M. Granovetter, 'Economic Action and Social Structure: The Problem of Embeddedness', American Journal of Sociology, 91(3), 1985, pp. 481-510.

73. W. Ocasio, 'Towards an Attention-based View of the Firm', Strategic Management Fournal, 18(Summer, special issue), 1997, pp. 187-206.

74. K.E. Weick, Sensemaking in Organizations (Thousand Oaks, CA, Sage, 1995).

75. E.g. F. Meyer-Krahmer \& T. Reiss, 'Ex ante Evaluation and Technology Assessment: Two Emerging Elements of Technology Policy Evaluation', Research Evaluation, 2(1), 1992, pp. 47-54; L. Georghiou \& D. Roessner, 'Evaluating Technology Programs: Tools and Methods', Research policy, 29, 2000, pp. 657-678.

76. Meyer-Krahmer \& Reiss, op. cit., Ref. 75, p. 47.

77. J. Oksanen, 'Research Evaluation in Finland: Practices and Experiences, Past and Present' (Helsinki, VTT Group for Technology Studies, Working Paper No. 51, 2000).

78. D.W. Bunn \& A.A. Salo, 'Forecasting with Scenarios', European Journal of Operational Research, 68(3), 1993, pp. 291-303.

79. B.R. Martin, 'Foresight in Science and Technology', Technology Analysis \& Strategic Management, 7(2), 1995, pp. 139-168.

80. Lerner, op. cit., Ref. 8.

81. S. Kortum \& J. Lerner, 'Does Venture Capital Spur Innovation?', NBER Working Paper Series No. 6846, 1998. 